RACE, IMMIGRATION, GENDER, AND THE POLITICS OF EXCLUSION

\title{
Somos los Abandonados: Mariel Cuban Stories from Detention and Resisting the Carceral State
}

\author{
Kristina Shull \\ UNC Charlotte, US \\ kshull1@uncc.edu
}

Through an analysis of government documents, media sources, migrant testimonies, made objects, and acts of protest, this essay examines the impact of the United States' indefinite detention of Mariel Cubans-and their resistance - on immigration detention policy and the rise of the carceral state during the Reagan administration. As the United States first detained Mariel Cubans on military bases and then in US prisons, Cubans continually challenged their indefinite detention and US attempts at deportation through legal, political, and poetic claims, as well as uprisings-culminating in a two-week takeover and standoff at two prisons in Atlanta and Louisiana in 1987, the longest prison uprising in US history. Throughout, the Mariel migration remained at the center of the Reagan administration's immigration and prison policy discussions, ushering in a new era in detention and immigration restriction.

This essay also considers the role of Mariel Cuban storytelling as a powerful form of resistance to detention, and the extraordinary anti-Blackness, queerphobia, and criminalization surrounding this migrant group, then and now. It concludes by reflecting on contemporary coalitional efforts to uplift the stories of Cubans recently—or still-imprisoned, some having arrived with the Mariel Boatlift, and possibilities for abolitionist futures.

Keywords: Mariel; Mariel Cuban Boatlift; immigration detention centers; prisons and policing; United States foreign policy; LGBTQ; immigration

Lene, born Lenin, arrived in the United States "terribly confused and fearful" at age sixteen with the Mariel Boatlift, a large-scale migration of nearly 130,000 Cubans to southern Florida during the summer of 1980. Traveling alone and with no ability to speak English, he says elders advised him to change his name and his birth date so that he could fit in with US society and find work. After being screened by INS agents in Key West, he was sent to the Orange Bowl temporarily, and then to Fort McCoy, Wisconsin, to await a sponsor and release.

In a few short weeks, Lene's sponsor Berniece Taylor, 57, was murdered in her home. According to Lene, he had gone out for the night to see his girlfriend and English interpreter and was not present when the murder took place. But fearful of implicating his friends, he withheld this alibi from the police. Having just turned seventeen, Lene was tried as an adult and given a life sentence in prison in September of 1980, with the judge's understanding that under Wisconsin law he would be eligible for parole after thirteen years. But due to immigration reforms in the 1980s and 1990s mandating detention and deportation for those convicted of aggravated felonies, Lene was never granted parole. In an appeal for a retrial in the spring of 1981, his lawyer argued that the "melee of confusion" at Camp McCoy gave Lene "no opportunity for him to in any way comprehend the involvements that he ultimately became entangled with." Basing the appeal on an overall lack of evidence, the lawyer also claimed discriminatory treatment by the police and prosecutor during the investigation and trial played into "the latent prejudices that people in this area and this state and perhaps in the United States may have with respect to this time." Lene remains in prison in Wisconsin to this day, where he maintains his innocence and asks the US government to deport him. ${ }^{1}$

\footnotetext{
${ }^{1}$ See: casesprison.files.wordpress.com/2018/12/Lene-Cepedes-Torres-App-for-deportation.pdf. I have so far been unable to reach Lenin for comment. Thanks to Omar Granados at the University of Wisconsin La Crosse and Peg Swan at Forum for Understanding Prisons who brought his case to my attention. Granados says that locally, multiple versions of the story continue to circulate.
} 
Forty years on, Lene's story points to the Mariel migration's most tragic legacies: its impact on the expansion of the US carceral state and the harms of indefinite detention on individuals. My intention here is not to linger on the public xenophobia or official narratives of criminalization surrounding the Mariel migration, themselves fueled by anti-Blackness, queerphobia, and ableism. Nor is it to idealize or exceptionalize individuals like Lene. Rather, I point to his story-and those of other Mariel Cubans who have been subjected to some of the most abusive and silencing impacts of mass incarceration in the modern era-for how it survives, endures, and calls out. What do stories from spaces of detention reveal?

The 1980 Mariel Cuban migration ushered in a sea change in US border policing and prison policymaking. Not only did a small but significant number of Mariel Cuban arrivals find themselves ensnared in rising mass incarceration trends in the United States during this time, but their positionality-in time, space, and identity-helped drive these trends.

The criminalization of migration itself since the 1980s a phenomenon called crimmigration, has melded criminal legal and immigration systems together in ways that have made them increasingly indistinguishable-from local law enforcement's co-operation with Immigration and Customs Enforcement (ICE) to the building of "mixed-use" facilities co-managed by ICE and the Bureau of Prisons. Immigration violations now comprise over half of all federal charges, while many migrants now serve lengthy prison sentences for reentry before entering the administrative detention and removal process (See Greene et al.). The United States maintains a vast system of nearly three hundred local, federal, and private immigration detention facilities that has grown ten-fold since the mid-1980s and by early 2020 has imprisoned a high of over 50,000 migrants a day and 500,000 a year across the country. ${ }^{2}$ Current public discourse, as well as much detention and carceral studies scholarship, does not pay full enough attention to the ways in which the US government's response to Mariel fueled the rise of crimmigration, nor its central role in shaping modern mass incarceration in the United States more broadly.

The legacies of Mariel are myriad; this singular migration event continued to haunt the Reagan administration as it developed a range of retaliatory and preventive immigration enforcement measures which became embedded in immigration detention function and design. Mariel was a central impetus driving the administration's Mass Immigration Emergency Plan of 1983 mandating detention's expansion, as well as its turn toward prison privatization that same year. Public and mass media hysteria surrounding Mariel criminality also contributed to heightened policing and the expansion of carceral geographies in Reagan's globalized War on Drugs. Finally, the fraught and fractured politics surrounding Mariel coalesced "good" versus "bad" immigrant narratives still shaping immigration debates today.

Forms of Cuban resistance in detention and community contestations played a central role in shaping these policy outcomes. Through an analysis of government documents, media sources, migrant testimonies, made objects, and acts of protest, this essay examines the impact of the United States' indefinite detention of Mariel Cubans-and their resistance-on immigration detention policy and the rise of the carceral state during the Reagan administration. It explores the ways in which Mariel Cubans resisted from the inside, and led inside-outside and coalition organizing on the outside to challenge their detention. Inside-outside organizing is a strategy prioritizing the leadership and knowledge of incarcerated people with support from collaborators on the outside.

As the United States first detained Mariel Cubans on military bases and then several thousand deemed criminal, deviant, or mentally ill in US prisons, Cubans continually challenged their indefinite detention and US attempts at deportation. They made legal, political, and poetic claims, as well as waged hunger strikes and coordinated unrest-culminating in a two-week takeover and standoff at two prisons in Atlanta and Louisiana in 1987, the longest prison uprising in US history. Throughout, the Mariel migration remained at the center of the Reagan administration's immigration and prison policy discussions that shaped a new era of detention and immigration restriction. I conclude by reflecting on contemporary coalitional efforts to uplift the stories of Cubans recently-or still-imprisoned, some having arrived with the Mariel Boatlift, and possibilities for abolitionist futures.

\section{From the Boat to the Prison}

The passage of the 1980 Refugee Act shortly before the Mariel Boatlift began promised to align US asylum policy with the United Nations Refugee Protocol of 1967, opening possibilities for a broadening of the definition of refugee. However, the United States has long wielded categories of refugee status as in foreign policy

\footnotetext{
${ }^{2}$ Due to the COVID-19 pandemic, daily detention numbers reached their lowest since the mid-2000s, at 15,136 in April 2021. They are again rising and near 25,000 in September of 2021. Available at ICE.gov.
} 
tool. Prior to 1980, the United States had predominantly welcomed Cuban exile groups, granting them visa waivers and parole on Cold War grounds of their fleeing Cuba's communist revolution. But shortly after the first arrivals of Mariel Cubans in South Florida in the spring of 1980, reports of Fidel Castro purposefully infiltrating the boatlift with criminals and other social "undesirables" began to circulate in US media. ${ }^{3}$ Taking place in the year of the 1980 Carter-Reagan election, the Mariel migration also coincided with a growing number of arrivals of Haitian asylum-seekers by boat, further stoking public xenophobia. ${ }^{4}$ The Carter administration's discriminatory treatment of Haitian asylum-seekers in the late 1970s, subjecting them to near-blanket detention and deportation before the incoming Reagan administration would expand these practices as official policy, helped lay the groundwork for Reagan's right turn. ${ }^{5}$

Despite initially promising to welcome Mariel Cubans "with open arms" in line with prior Cold War US refugee policy, the Carter administration quickly changed course. Rather than allowing the new Cuban arrivals to avail themselves of provisions of the 1966 Cuban Adjustment Act or the 1980 Refugee Act, the US government instead gave Mariel Cubans a temporary "Cuban/Haitian Entrant" legal status. While roughly half of the arrivals were reunited with family members or resettled in the Miami area in a relatively timely manner and eventually able to adjust their status, the other half were sent to one of four military bases across the country for "processing"-to await sponsorship and resettlement. ${ }^{6}$ The demographic composition of the Mariel migration differed from those who had emigrated previously, largely explaining this group's negative public reception. Whereas earlier exiles were mainly older, white, and upper- or middle-class Cubans seeking family reunification, Mariel Cubans were predominantly younger, male, and single, albeit more educated on average (See García p. 68). An estimated thirty to fifty percent of the overall Mariel migration was AfroCuban, but they had divergent fates from the overall population: only eight to ten percent of Mariel Cubans who were processed in Miami and quickly resettled with family members were Black, whereas Black Mariel Cubans made up seventy-five percent of those detained long-term at Fort Chaffee or in federal penitentiaries. Also, seventy percent of the boatlift was male. Although it is impossible to know the overall number of QTGNC (queer, trans, and gender non-conforming) Mariel migrants because of mis-reporting and the state's lack of record-keeping, this group received a disproportionate amount of media attention. ${ }^{7}$

Symbolizing a confluence of threats facing the nation, Mariel occupied a central position in what I call the Reagan imaginary. Shaped by neoconservative politics, neoliberal economics, and long-standing mythologies of settler colonialism, the Reagan imaginary is a vision and strategy of white nationalist state-making. I assert that immigration detention operates as a form of counter-insurgency in this imaginary, a strategy of pre-emptive warfare targeting those deemed enemies of the state. ${ }^{8}$ Once in office, Reagan quickly moved to retaliate against Cuba for the Mariel migration, expand immigration detention practices, and further criminalize migration. While some Mariel Cubans subjected to indefinite detention continued to languish in US prisons, subsequent administrations have affirmed and expanded upon Reagan's policy of detention as deterrence, all in the name of preventing "another Mariel."

By responding to Mariel as an envisioned "mass immigration emergency" and a portent of future migration crises to come, the Reagan administration weaponized existing Cold War foreign policy and border enforcement trends while also forging news tools of exclusion. Framing the crisis not only in Cold War terms, the Reagan administration's calls to expand the carceral state through a globalized War on Drugs also reflected domestic political goals of enhancing law enforcement functions to contain the specter of Latin American mass migration.

Anti-Blackness surrounding Mariel Cuban migrants also converged with Reagan's signaling on race and crime that predominantly targeted African Americans, with xenophobia bolstering the administration's resolve to enhance the state's punitive functions. ${ }^{9}$ White House policy discussions often conflated the issues of immigration and crime as the Reagan administration allied itself with the restrictionist view that

\footnotetext{
3 See Aguirre, 1994, 1997; García.

4 See Lindskoog; Loyd and Mountz.

${ }^{5}$ Systems of incarceration have always disproportionately targeted specific groups of people-based on race, most clearly, but also on gender, class, dis/ability, and ideology. These markers of difference have shaped immigration policy and detention practices. As Kelly Lytle Hernández argues, today's prison landscape must be understood as an extension of the United States' history as a white settler colony, operating within and alongside legacies of immigrant exclusion, slavery and Jim Crow-era segregation, and Native American removal. See K.L. Hernández, 9.

6 The four military bases were Eglin Air Force Base in Florida, Fort Chaffee in Arkansas, Fort Indiantown Gap in Pennsylvania, and Fort McCoy in Wisconsin. See Larzelere, The 1980 Cuban Boatlift, for boatlift statistics.

7 See Hay p. 32; Peña; and Capó 2010.

${ }^{8}$ See Shull 2021.

9 See Simon; Alexander.
} 
immigration posed a threat to public safety. The incoming Reagan administration also marked a right turn in prison philosophy, confirming a shift away from rehabilitative models towards punishment as the primary goal of incarceration. In 1981, Reagan's attorney general announced a new policy position on detention as a deterrent to would-be asylum-seekers, which would have tragic consequences for subsequent migrant groups, most notably Haitians and Central Americans. ${ }^{10}$

As Reagan policymakers turned their attention to the Caribbean to combat the perceived nexus of crime, drugs, and immigration, Mariel remained a central preoccupation in the Reagan imaginary where the boundaries of border policing stretched well beyond the US-Mexico divide. Obsessions with Mariel Cuban criminality and curbing drug trafficking networks in Colombia, Cuba, Central America, and Miami all became justifications for boosting defense, carceral, and private sector spending and for extending law enforcement efforts abroad. In the fall of 1981, President Reagan announced to the nation that "A wave of violent crime has engulfed our nation," and, "Just as a strong national defense is essential to protect us from our enemies in other lands, a strong domestic defense is necessary to protect us from our enemies within our own country" (Draft Presidential Crime Speech). Reagan's War on Drugs further accelerated border and police militarization and the enfolding of migrants into the criminal legal system.

Although numbers varied even within government records, in addition to nearly 2,500 Mariel Cubans whom the United States deemed excludable on grounds of criminality or mental illness and detained indefinitely since arrival, several thousand more were arrested and re-incarcerated in subsequent years after resettlement-mostly as a result of elevated policing and surveillance nationwide. ${ }^{11}$ Even though the US government determined that no more than one thousand Mariel Cuban arrivals, or less than one percent, had committed serious crimes in Cuba, the false belief that 40,000 had spent time in prison in Cuba continued to circulate amongst police departments nationwide. ${ }^{12}$ Continued attempts by the United States to repatriate Mariel Cubans throughout the 1980s, suspended in a "legal fiction" of being physically present yet legally excluded, would play a central role in the Reagan administration's plans to build prisons and alleviate overcrowding. ${ }^{13}$ The indefinite detention of Mariel Cubans would recede from public view until Cuban-led prison uprisings in 1987 spurred new forms of state retaliation.

\section{Detention Stories}

And yet, Mariel Cuban voices from detention have posed powerful challenges to detention itself, as well as the extraordinary anti-Blackness, queerphobia, and criminalization surrounding this migrant group, then and now. What forms have testimonies and acts of protest taken, and how may they be read against the raced and gendered strictures of immigration law, media narratives, and US-Cuban foreign policy imaginaries? Cuban stories from detention often reflected the broader Cold War contestations and migration politics surrounding them. But they also defy common conceptions and binaries driving these divides. As the Mariel migration exposed fault lines of contested memories of the Cuban revolution, the voices of those most excluded from its promises-especially those policed and imprisoned in both nations-namely Black, hypersexualized, queer, trans, and/or disabled Cubans, tell us more about what constitutes a migration "crisis."

Although Mariel is commonly held up by immigration restrictionists as a haunting example of how "out of control" borders raise crime rates and harm US workers, historian Julio Capó, Jr. contends that much conventional wisdom surrounding Mariel "is based on falsehoods rooted in Cold War rhetoric" "The White House Used This Moment"). Indeed, the memory of the boatlift as a crisis is sustained not only by restrictionists on the right, but across academia and US popular culture. But what kind of crisis was it? And for whom? A simple YouTube search for the term "Mariel Cuban Boatlift" today, or the widespread popularity of the 1983 film Scarface, reveals how a stigma of criminality associated with this migrant group endures. These misconceptions circulated transnationally, in part fueled by Fidel Castro himself, but also by xenophobia surrounding Afro-Cuban, disabled, queer and transgender members of this migrant group. Capó writes that Castro's propaganda scheme was so successful because it "found an eager audience in the United States among those who found it useful to fuel the nativist furnace" ("The White House Used This Moment"). Often lost amid larger debates was the personal suffering of Mariel Cubans who were subjected to indefinite detention throughout the 1980s, and beyond.

\footnotetext{
${ }^{10}$ See Loyd and Mountz; Shull 2021.

11 See Larzelere p. 434; Young pp. 124-5.

${ }^{12}$ See Martínez.

${ }^{13}$ See Young pp. 130-1; Macías-Rojas.
} 
Experiences of forced migration and detention are singular emergencies; their traumas, difficult to identify, voice, and write about. In the words of Simon, a Mariel Cuban detained at Fort Chaffee, Arkansas, in 1980, "For me it was a terrible dream. You can't imagine anything." These experiences are visceral-a "terrible dream," unimaginable, unknowable. Indeed, carceral spaces function by design to silence the voices of those imprisoned.

Meanwhile, states co-opt migration crises to their own ends. While individuals and communities in transit or in detention experience a crisis in real-time, narratives of immigration crisis that circulate in the public sphere (e.g. in media and political debates) are often mere constructions, relying on longstanding ideasmyths-about what defines a nation. As Dan Kanstroom argues, today's US immigration enforcement regime is a "living legacy of historical episodes marked by ideas about race, imperialism, and government power that we have largely rejected in other realms" $(\mathrm{x}) .^{14}$ Therefore, narratives that deem immigration a crisis, not for migrants but for the nation itself, deem bodies who do not have a "right" to occupy this land a threat to the body politic. Narratives that cast migrants and migrant groups as threatening, or in more sympathetic accounts as victims, sort good from bad, deserving from undeserving, utilizing language that generalizes and amplifies characteristics marking them as Other. These narratives flatten and silence lived experiences in service of defining the nation and its bordering logics. With state interests at stake, narratives of immigration crisis reflect a power struggle using rhetorics of war and counter-insurgency to silence dissent and to label rebellion as irrational and violent acts. These narratives work to discredit dissent and appear in official state documents and in mass media. ${ }^{15}$

Mariel Cubans' lived experiences countered their demonization by the Cuban and US governments, the media, and even the Cuban American community. For the imprisoned "abandoned ones," the crisis was multidimensional as they faced discrimination and persecution in Cuban and US contexts. The plight of Mariel Cubans subjected to indefinite detention was often eclipsed by Cuban American politics ranging from respectability to right-wing, or by leftist migrant rights organizing such as the anti-imperialism of the Central American peace and Sanctuary movements. ${ }^{16}$ Many detained Cubans aligned themselves with the anti-communism of the Reagan imaginary, making pro-US appeals. Yet their words and actions also rejected their treatment by the US government, especially the INS.

\section{Military Camps and QTGNC Cuban Resistance}

If I could choose a political party I would choose art.

-Jorge, detained at Fort Chaffee, 1980

Mariel Cuban life and resistance inside the military camps, contestations over the closure of Fort Chaffee, Arkansas, where Cubans were consolidated at the boatlift's end, and complex local and transnational politics galvanized the incoming Reagan administration's new policy of detention as deterrence. Government documents reveal how QTGNC (queer, trans, and gender non-conforming) migrants, especially, shaped detention policymaking and modes of retaliation that became embedded in detention's design. However, acts of resistance, oral histories, art, and Cuban-edited camp newsletters also show how Mariel Cuban migrants claimed dignity for their lives and identities while continually challenging their indefinite detention.

To Cuban migrants' detriment, the circulating belief that Fidel Castro purposefully infiltrated the boatlift worked to Cuba's advantage by alleviating the embarrassment caused by unexpected numbers of Cubans trying to emigrate. Scholars have documented how the boatlift became a homophobic nationalist campaign. Eyewitness accounts confirm that Cuban officials were releasing people whom Castro deemed escoria (trash) or lumpen-so-called loafers, criminals, and mentally ill-from prisons and forcing them onto boats bound for the United States. Castro remained fairly silent on the issue throughout the boatlift; however, in a May Day rally speech he attempted to shatter the notion that those wanting to leave Cuba were anti-communist dissidents. Castro used homophobic language to discredit refugees by calling them escoria, lumpen, and flojito (limp-wristed)..$^{17}$

\footnotetext{
${ }^{14}$ See also Zolberg.

${ }^{15}$ See Camp p. 17.

${ }^{16}$ Scholars who trace Mariel's role in the rise of the US carceral state include García 1996; Dow; Lipman; Macías-Rojas; Loyd and Mountz; and Young.

${ }_{17}$ State repression of homosexuality-particularly gender-nonconforming and "passive" male homosexuality-was a well-documented aspect of Cuban society under the revolution, which championed the image of a masculine workingman. See Capó 2010; Fernández pp. 23-41; Sierra Madero 2018.
} 
Cuba did not cooperate with US efforts to obtain Mariel Cuban prison records either, further complicated by the fact that many were jailed in Cuba for reasons the United States might not consider criminal such as participation in the black market, homosexuality, or dissenting with the Communist government. One young man, Manuel from Fort McCoy, for example, claims he was wrongly imprisoned in Cuba for merely being in the vicinity of a theft motivated by hunger. When the boatlift began, Cuban officials came to the prison to interview him. They "became aware of my negative attitude towards the system, and they told me to gather my things" (Alvarez). He says he was then escorted to one of five buses leaving from the prison to Mariel harbor.

Oral histories describe Mariel Cuban efforts to secure exit permits and confirm the state's interest in purging Cuba of homosexuals. One young man, Antonio Conchez, "had gone prepared with an eye-catching outfit, my hair messed up and a little bit of makeup on my eyes and face. I also spoke with a fake voice, exaggerating my mannerisms so that they would be convinced that I was a homosexual" (Peña 488). Another recalled seeing a poster while waiting for an exit permit that read, "Homosexuals, get out; scum of the earth, get out" (Capó "Queering Mariel" 87). Others say they were threatened with jail time if they did not agree to leave the island. Cubans may have exaggerated their sexual orientations and criminal histories in order to leave the country, adding to misreporting in the United States.

Upon arrival, these confusions were compounded by the tension between the United States' acceptance of anti-communist refugees and its immigration policy barring homosexuals (still a potential ground for exclusion in US immigration law that would not change until 1990). Because of the sheer number of arrivals and because Cubans were largely un-deportable, INS also relaxed its enforcement of determining exclusion based on homosexuality in September of 1980. This unclear "don't ask don't tell" policy led to a lack of data collection that in turn contributed to media misinformation. However, it also opened up spaces for migrants to maneuver within. As QTGNC Cuban migrants were detained and consolidated on military bases, they navigated these liminal spaces to affirm and demand respect for their identities.

In the late spring of 1980, one month after the Mariel Boatlift began, administrators at the makeshift Cuban camp Fort Libertad on the Eglin Air Force Base in Florida noted "processing problems." Refugee grievances over slow out-processing and camp conditions resulted in a series of small-scale uprisings. A week later, Cubans staged a hunger strike at Libertad, which according to reports, "spread throughout the entire camp" ("Significant Activities, 18 May 80"). One of the leaders of the strike said he would not speak until he could speak to his political advisor. It is unclear whether this was someone inside or outside of the camp, but it speaks to Cubans' careful organizational strategies. Thirty Cubans issued a list of grievances requesting to be released by four p.m. that day, "or else!" By seven p.m. the demonstration turned into a confrontation and several Cubans were injured. Follow-up Federal Control Center reports describing logistical and administrative breakdowns state: "The perception of coming from an armed environment in Cuba to another prison camp in the United States can be quite explosive" ("Significant Activities, 18 May 1980"). However, the reports ultimately blamed unrest not on detention itself, but on the military police's lack of authority to intervene and make arrests, as well as a lack of segregation between "problem groups" and "family groups." The list of problem groups included single men, criminals, political agitators, prostitutes, and homosexuals.

Security problems continued to recur, and experts noted early on the detrimental effects of long-term detention on refugees' mental health. Shortly after Reagan's inauguration and the consolidation of Mariel Cubans at Fort Chaffee, Arkansas, camp administrators warned in March of 1981: "The lack of alternatives for these people could develop into a substantial security problem ... Staff consensus-including that of psychologists and psychiatrists-is that both their mental health and ability to adapt to life in the United States would be enhanced if placed in locations/situations with other than a refugee camp atmosphere." The CubanHaitian Task Force also advised, "The longer the Cubans remained in camps, particularly the consolidated Fort Chaffee, the links between 'camp life' and American society became more tenuous ... the resettlement centers were intended as an interim location to await placement into American society, and not as its substitute" ("Operational and Policy Issues at Fort Chaffee").

Negative effects of long-term detention and growing resistance did not elude camp administrators and mental health experts, but their comments also point to the US government's broader ideological view of Mariel Cubans-whether vulnerable or criminal, they posed a national security threat nonetheless. Demonstrations, uprisings, hunger strikes, violence, medical and mental health crises, suicides, and attempted suicides continued to plague detention operations, which administrators openly connected to mental health needs. As the incoming Reagan administration resolved to keep refugee populations separated from the American public in increasingly punitive conditions, these problems only worsened. 
In response to Cuban unrest at Fort Chaffee, Arkansas, and at Governor Clinton's urging, the Pentagon granted federal troops the emergency power to use restraining force to contain Cubans within the military bases across the country where they were being processed, and the White House promised that no more Cubans would be sent to Fort Chaffee. However, as the boatlift drew to a close, Fort Chaffee became the consolidation site for 9,500 unsettled Mariel Cubans in the fall of 1980, where operational problems would continue. A total of 19,060 Cubans were processed through Fort Chaffee until the fort's closure in February 1982 sent the remaining 392 who were labeled "antisocial" to several prisons across the country. There they joined 1,200 Cubans who were already imprisoned based on suspected felony charges. An additional 600 labeled "serious mental cases" were housed at St. Elizabeth's Hospital in Washington, DC. ${ }^{18}$ Many of them, still with indefinite legal status and unable to repatriate due to cold relations between the United States and Cuba, remained in INS or Bureau of Prisons custody for years, and some for well over a decade.

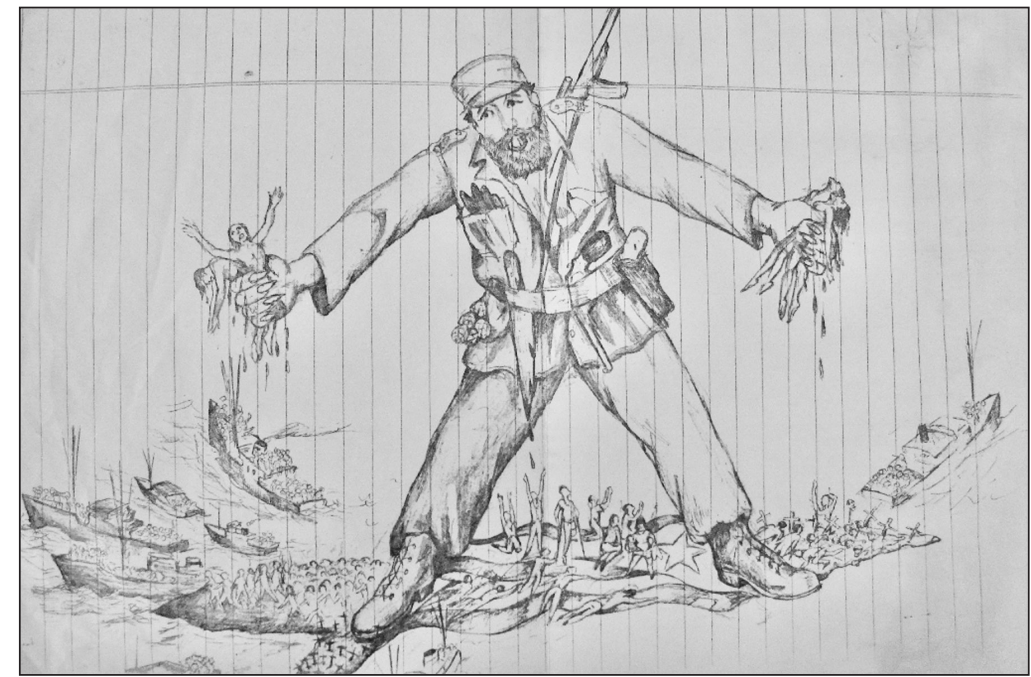

Figure 1: "Anti-Castro drawing by an unnamed Mariel Cuban detained at Fort Chaffee, Arkansas." 1980. Cuban Heritage Collection, University of Miami.

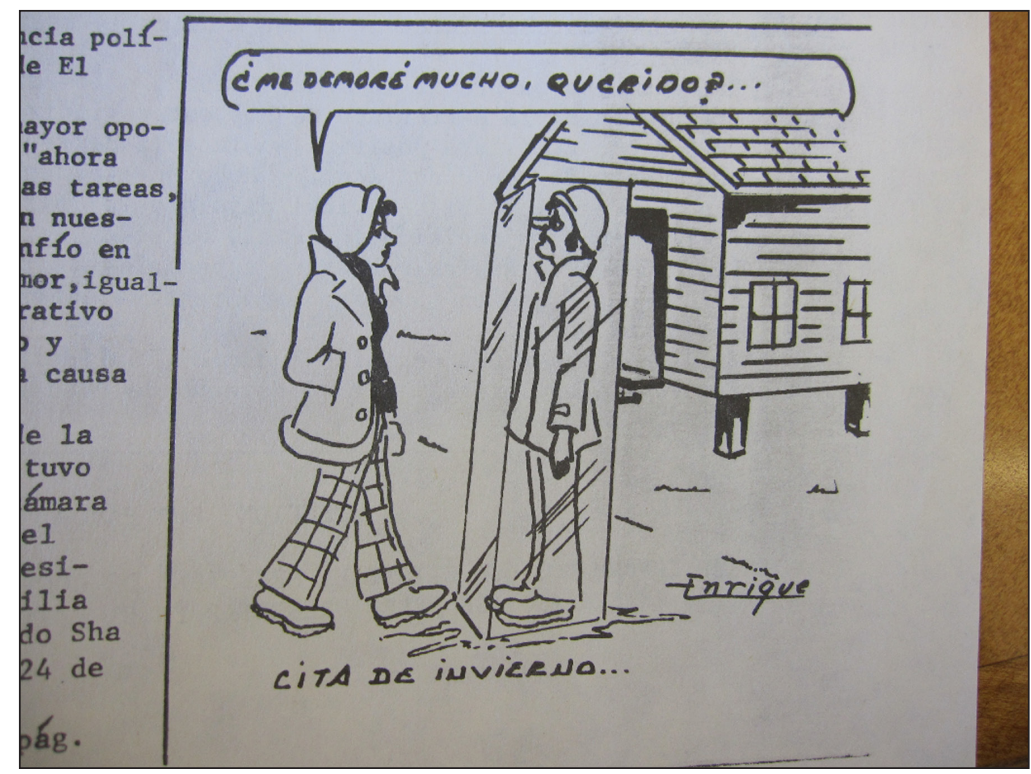

Figure 2: "A cartoon drawn by Enrique." 1 Nov. 1980. La Vida Nueva newsletter at Fort Chaffee. Cuban Heritage Collection, University of Miami. A woman approaches a man frozen in ice, asking in Spanish,

"Did it take me long, dear?" Not only referencing cold weather, the cartoon expresses Cubans' frustrations with long processing times at the camp and feelings of uncertainty.

\footnotetext{
${ }^{18}$ See Larzelere p. 379, p. 434.
} 


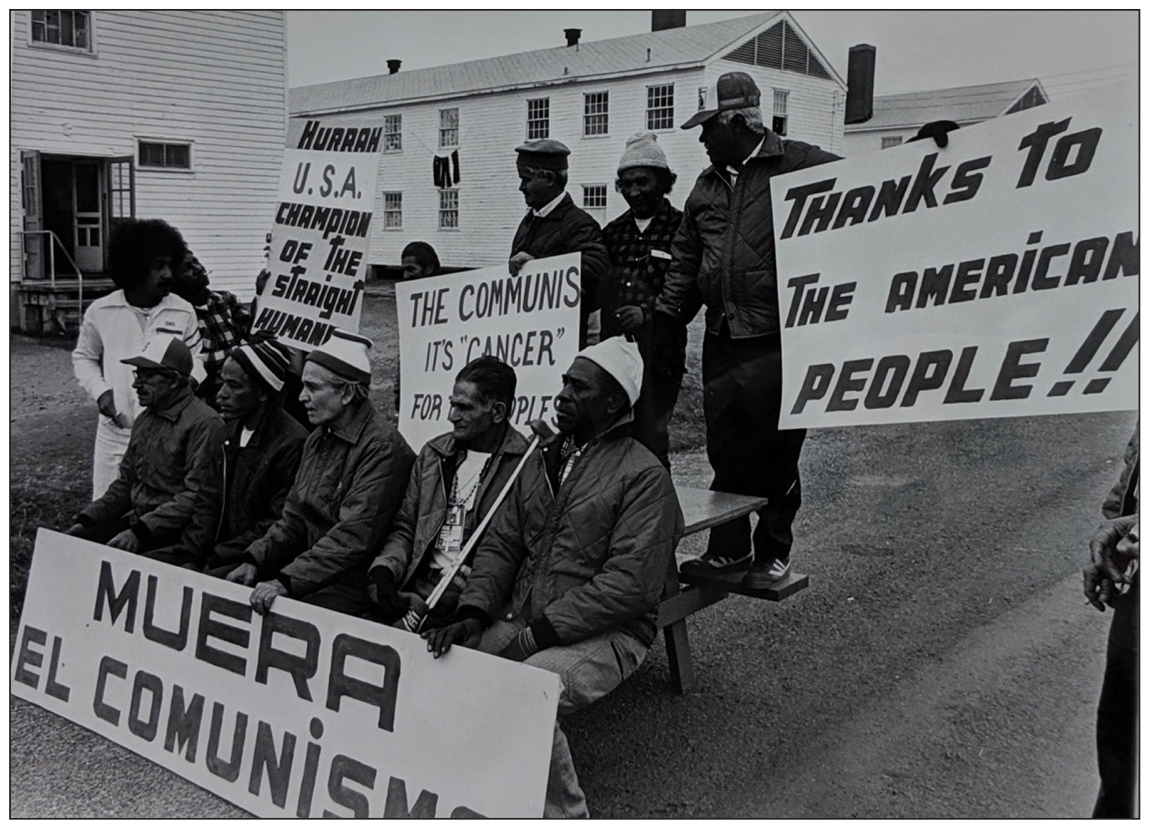

Figure 3: "A group of older asylum-seekers at Fort Chaffee." 1980. Charles Lee Hughes Fort Chaffee Photograph Collection, University of Arkansas Special Collections. Known as the Abuelos, the older asylum-seekers held a pro-US demonstration in the fall of 1980. However, some camp administrators alleged that the event was staged for pro-Reagan political purposes.

The Cuban-Haitian Task Force, formed by Carter and continued by Reagan to manage the military camps, weighed options for handling the four "problem" groups it identified as slowing the resettlement process: the "criminal element," "unaccompanied minors," "mental illness," and "homosexuals." Under heightened public and official scrutiny, members of these groups experienced a range of segregation and punitive practices in detention that, in effect, confirmed their deviance, heightened suffering, and prolonged detention times. Despite xenophobic responses to resettlement camps expressed by local communities, Mariel Cubans also received community support, especially in the boatlift's earlier days preceding camp consolidation. KKK members demonstrated outside Fort Chaffee's fences, but so did those in support of Cubans receiving refugee status. ${ }^{19}$

Cuban-edited camp newspapers and artistic expression offered space for Mariel Cubans to confront and contest their liminality. At first, they seemed fairly free to re-create social life in the refugee camps. Single men, single women, QTGNC migrants, and families were housed separately, mostly by choice, and a black market of commodities, including sex, was not regulated. ${ }^{20}$ A majority of unaccompanied minors were sent to Fort McCoy, Wisconsin, while QTGNC migrants were unofficially sent to Fort Indiantown Gap in Pennsylvania. The newspapers La Libertad at Fort Indiantown Gap and La Vida Nueva at Fort Chaffee acknowledge gender non-conforming groups, mostly in relation to STI education. Reflecting transnational homophobia, an interview with a Cuban named Tamayo in La Libertad relates, "problems which occur with the homosexuals are being controlled, since generally they keep to their own side of the area or around their barracks, or get sent to other areas. Here in America, homosexuality is not a crime, so it seems gays are enjoying their newfound freedom, perhaps in an exaggerated way, and causing problems by agitating straight men and families, who do not like their children to see or hear certain things" (La Libertad, 1 Aug. 1980). This assumption of freedom, however, became increasingly problematic.

Oral histories recount how US-Cuba student solidarity formations prior to Mariel and the queer community of Metropolitan Community Church (MCC) in Philadelphia came to support QTGNC migrants at Fort Indiantown Gap. Three months before the boatlift began, Penn law student Fernando Chang-Moy traveled to Cuba over winter break with Columbia University's Black Law Student Association. A Mexican academic introduced Fernando to Havana resident Eloy Gonzalez, who invited Fernando into the city's

\footnotetext{
19 See Shull, 2014; Loyd and Mountz pp. 54-60
}

20 See Fernández pp. 42-3. 
clandestine, "counterrevolutionary" queer scene. Three months later, Fernando's mother received a call from Eloy, who arrived with the boatlift and was camped at the Orange Bowl, needing a sponsor and a place to stay. She hosted Eloy and a few friends at her home in Miami before Eloy resettled in Philadelphia. From this friendship, Fernando was inspired to join "a liberal arm of lawyers" from the National Lawyers Guild who visited Fort Indiantown Gap to interview detained Cubans and facilitate their resettlement (Chang-Moy).

Mark Segal, activist and founder of the National Gay Newspaper Guild and the Philadelphia Gay News, recounts how he was one of the first to learn of QTGNC Cubans detained at Fort Indiantown Gap through a friend at MCC. Wanting to get the "scoop," Segal and a friend drove out to the heavily guarded camp. Segal wore a black Nehru shirt with cardboard in the collar, posing as a priest and telling US Army guards he was a representative of MCC there to help "resettle the homosexuals." Looking disgusted, a guard directed them to two barracks. Segal recalls, "It was like a party was going on in that place. There were drag queens throwing material around each other, they were trying on makeup ... even in captivity, in an Army base, they felt that freedom. It was amazing." When Segal said they were from a gay newspaper, "the whole place lit up. A gay newspaper! Gay people are here! And they all came running over ... it was very festive and very loud. And about half an hour later we found ourselves surrounded by the Army with rifles drawn." They left with their camera and tape recorder. A few days later, Segal received a call from a general demanding the tape and film, but it was too late. "We were the first newspaper in America to report on the gay Cubans in Pennsylvania" (Segal).

Despite stories of solidarity and freedom, Mariel Cuban detention became increasingly punitive. Efforts to obtain sponsorship and resettlement for Cubans involved cultural training and expressions of heteronormative US values; by contrast, those who remained excludable were rendered invisible by continued detention. Whether bids for sponsorship and public sympathy or not, Cubans often expressed strong anti-communist and anti-Castro sentiment through demonstrations, public appeals, and artwork reflecting these themes [see Figures 1 and 3].

By the time Reagan entered office in January of 1981, five thousand Cubans who had been consolidated at Fort Chaffee, Arkansas, remained-many were single men, Black, queer, and/or trans, and had difficulties finding sponsors (see Figure 4). Sylvia Gonzalez of the Cuban-Haitian Task Force noted that queer life at Fort Chaffee was "freer" than in Cuba or the United States. However, "We have to impress upon them that homosexuality is not an accepted thing by Americans at large ... once they've been assigned a sponsor, you'll see that the eyebrows tend to grow out and the make-up fades as they prepare for reality" (Hoeffel). That gender nonconformity proved a liability outside the camp says more about the severity of discrimination across US and Cuban society, however, than it does about so-called freedom in detention. Working against pervasive

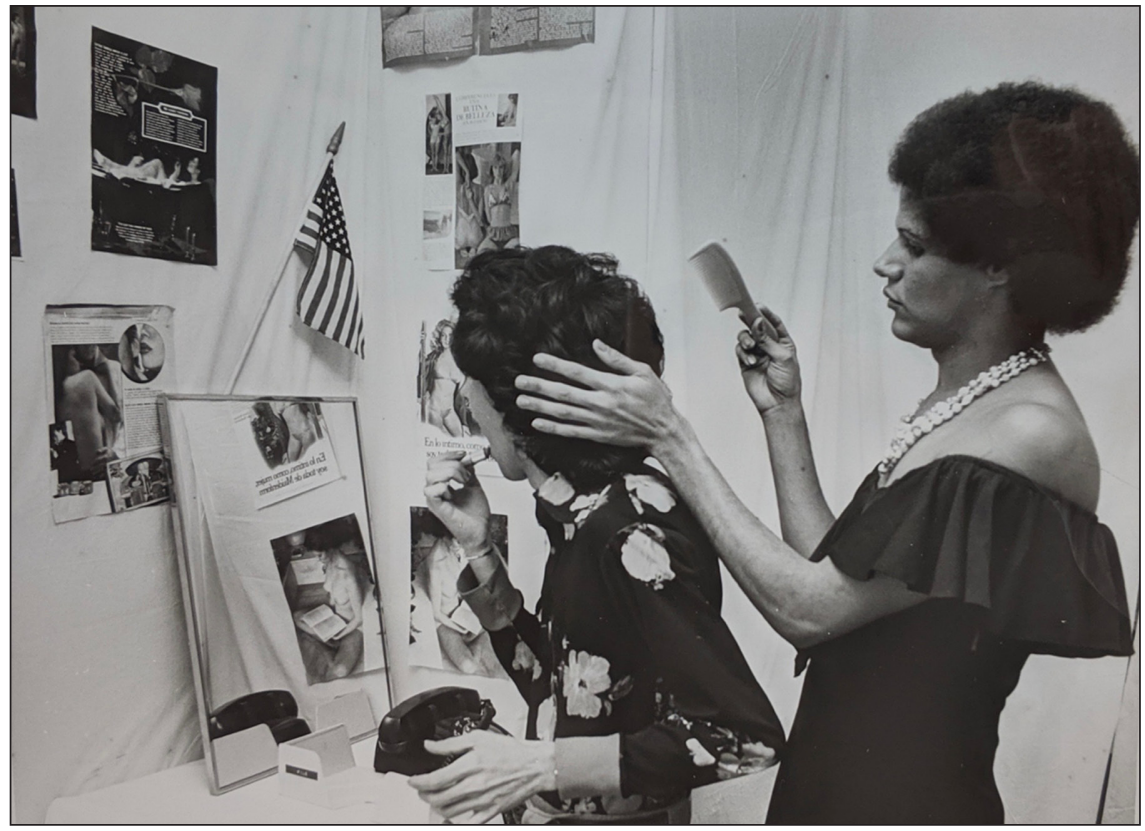

Figure 4: "Two gender non-conforming individuals grooming in their barracks at Fort Chaffee." 1981. Charles Lee Hughes Fort Chaffee Photograph Collection, University of Arkansas Special Collections. 
anti-Blackness and homophobia, sponsor organizations pressed Cubans to demonstrate a willingness to "fit in" with US society. Paula Dominique of the Church World Service told the New York Times, "There are people who call up and request a white, college-educated Cuban who speaks English ... We remind them that we're not a Sears catalogue" (qtd. in Hoeffel).

Newly-elected Arkansas Republican governor Frank White, who unseated Bill Clinton, received support from top Reagan administration officials who affirmed White's campaign to remove Cubans from Fort Chaffee and the state. Chief of Staff James Baker reassured him, "Nobody wants these people," and Vice President George Bush wrote that handling the "undesirables" was a "high priority in the administration" (Bush). Such was official language as the administration scrambled to mitigate fallout from the visibility of the Mariel crisis but struggled to find a state or site willing to accept Cuban refugees. Considering a pitch for a private contract facility in Montana, they instead transferred the remaining Cubans at Fort Chaffee to prisons throughout the country in 1982. The administration labeled it an "interim" solution that would be "faster and millions of dollars less expensive" than building a new detention center-a portent of detention trends to come as ad-hoc detention solutions solidified into permanence ("Termination of Ft. Chaffee Operations").

Imprisoned Cubans refused to accept their fates, however, resisting detention from the outset in myriad ways including legal challenges. Some began filing individual habeas corpus claims in 1980; several were decided in their favor, resulting in their release. In November of 1982, one thousand jailed Cubans filed a class-action lawsuit challenging their indefinite detention and claiming that undocumented migrants should have due process rights, but in 1986 the $11^{\text {th }}$ circuit upheld the indefinite detention of Mariel Cubans in Garcia-Mir v. Meese. ${ }^{21}$

Asylum claims can also be a powerful site of resistance. One such claim was that of Fidel Armando TobosoAlfonso, who arrived with the Mariel Boatlift and was paroled into the United States in 1980. But INS redetained him and terminated his parole for possession of cocaine, deeming him deportable for this crime of "moral turpitude." In response, Toboso-Alfonso filed a political asylum claim in 1985 based on the 1980 Refugee Act's protection of members of "a particular social group"-in this case, homosexuals. INS argued such a persecuted group did not exist, but Toboso-Alfonso demonstrated that Cuban police kept a file on homosexuals, thus documenting a decade of discrimination he faced in Cuba before arriving in the United States. In 1990, the court found he had experienced persecution in Cuba for being gay, and Toboso-Alfonso won his freedom.

Matter of Toboso-Alfonso was the first successful asylum case defining homosexuals as a persecuted group, effectively challenging the United States' Cold War refugee paradigm. Also in 1990, the United States repealed homosexuality as grounds for inadmissibility in immigration law in response to mounting pressures for gay rights. In 1994, Attorney General Janet Reno established this ruling as a new precedent for asylum cases. ${ }^{22}$ Today, such asylum cases are a powerful challenge to the prolonged detention of queer and trans migrants and have secured the release of many, effectively saving lives.

\title{
Prison Uprisings and State Retaliation
}

\author{
Dear Citizens of the United States, Thank You for your Hopes and Prayers. We do not want to blow it $!^{23}$ \\ -Banner at Oakdale detention center placed by Mariel Cubans, 1987
}

A few minutes after Tom Brokaw announced on the Nightly News on November 20, 1987, that the United States and Cuba had signed a new agreement to repatriate Mariel Cubans in Bureau of Prisons custody, a Cuban detained at a federal detention center in Oakdale, Louisiana, walked into the cafeteria and hurled an empty food tray at a service worker's head. He proclaimed it an act of protest, a cue prompting other Cubans in the dining hall to throw food, trays, and silverware against the walls. Guards subdued the disturbance. That night, while all was quiet, Cubans planned their rebellion. The next day, rumors circulated they were planning an escape. BOP moved all female staff out of the facility, fearing they would be raped, and called in the El Paso Border Patrol Tactical Team (BORTAC) for assistance. After dinner, two hundred and fifty Cubans gathered in the yard, brandishing homemade clubs and knives. They began to chant, "Somos los Abandonados (We are the Abandoned Ones)!" Over the next several hours, they clashed with guards, BORTAC, and FBI snipers, set fire to the library and administrative buildings, and took twenty-eight hostages. By nine p.m. they had total control over the prison.

\footnotetext{
21 See Erickson.

22 See Capó 2010.

23 See Hamm p. 22.
} 
Two days later, a small group of Cubans held at the Atlanta federal penitentiary set fires and began taking hostages, and eventually the entire prison, in a similar pattern. One Cuban was shot and killed by a guard in the only fatality during what would become the longest dual-prison takeover in US history, lasting until negotiations came to an end in Atlanta on December 3. During the siege, family members of detained Cubans appealed to the government and the public for compassion. One wife told the Associated Press, "I talked with my husband yesterday, and he said he'd rather die than go back to Cuba for no reason. I know many men in that prison. I came over with them in 1980 and this was bound to happen sooner or later" ("Associated Press Briefing"). Another family member said, "That place is nothing more than a concentration camp... They just picked these people up off the streets and brought them here." Ray Bourgeois, recently released from serving a six-month sentence at Oakdale for protesting US policy in Central America, told the Washington Post of recent Cuban suicide attempts there. "You could feel the tension building. Most of the Cubans had been detained indefinitely in this place that they thought was a strange jungle" (Maraniss). Meanwhile, federal officials told the media that attempts to escape from immigration detention were rare and "the rebellion of the sort that erupted here this weekend is even rarer."

This assertion was a lie-the Oakdale and Atlanta uprisings of 1987 marked only the most explosive flashpoint in the tragic saga of Mariel Cubans who were subjected to indefinite detention throughout the decade. Although immediately sparked by the news of impending deportations, the uprisings were a culminating response to the exceptional forms of violence-legal, physical, and psychic-inflicted upon Mariel Cubans subjected to indefinite detention. Up to and after the 1987 uprisings, Mariel Cubans waged a series hunger strikes and uprisings prompted not only by horrific prison conditions. They were also anti-deportation campaigns.

When the 1987 uprisings began, there were 3,800 Mariel Cubans in federal custody, with 1,050 at Oakdale, over 1,000 at the Atlanta penitentiary, and others in smaller numbers at sixty other jails and prisons across the country. In the seven years since the boatlift, around 2,500 had been detained indefinitely in federal custody. In addition, around 3,000 more had been arrested and re-incarcerated as a result of heightened policing of Mariel Cubans after resettlement (See Young p. 121). In 1983, INS worked with Dade County, Florida, and the Cuban-Haitian Task Force to compile a database to track Cubans and Haitians, shared with law enforcement officials across the country. And, a 1984 congressional testimony asserted the false belief among law enforcement that three thousand Mariel Cubans were "secret agents of Castro who had been spying on fellow exiles and running a vast underground network for addicting Americans to cocaine in a Castroinspired plot to spread social decay among the people of the United States" (Deni). In reality, the majority of Mariel Cubans who were re-detained after resettlement and deemed "excludable" were for crimes such as theft, minor drug offenses, and, most commonly, parole violations (Young 131-2).

Mariel Cuban repatriation was central to debates over prison budgets and bed space in the early 1980s. US-Cuba prisoner exchange negotiations during these years also paralleled recurrent Mariel Cuban unrest in detention. The attorney general routinely updated Congress on efforts to negotiate a repatriation agreement with Cuba, claiming it was "the only long-term solution for about 6,000, or more" Mariel Cubans, "many of whom are in custodial institutions, and who exacerbate the prison problem [emphasis added]" (qtd. in Macías-Rojas 57). Since the end of the boatlift in 1980, negotiations to exchange Mariel Cubans with US citizens imprisoned in Cuba on political grounds were ongoing, yet failed due to diplomatic breakdowns. The Carter administration nearly reached an agreement to return Mariel Cubans in US federal custody to Cuba by January of 1981, but once Reagan took office all communications with Cuba halted. A stalemate continued as the US government refused to accept former Cuban political prisoners unless Cuba would accept Mariel Cubans in return. ${ }^{24}$

Although the Reagan administration would not admit it, Jesse Jackson's visit to Cuba during his 1984 presidential campaign opened the way for the resumption of talks resulting in a US-Cuba "Repatriation List" agreement later that year. Although Jackson was a critic of Reagan's hard-line foreign policy and a champion for detained Haitians and Central Americans, he supported the deportation of Mariel Cubans in his negotiations for the release of US political prisoners in Cuba, and normalizing US-Cuba relations overall, as emphasized in a telegram he sent to Reagan after his trip. Jackson relayed that Castro was ready to discuss a "Mariel prisoner exchange immediately" and that Castro was amenable to such negotiations "because of my trip to Cuba." This is but one example of how the thorny politics surrounding Mariel Cubans often excluded them from leftist advocacy on behalf of detained migrants.

\footnotetext{
${ }^{24}$ See Leogrande and Kornbluh pp. 238-40.
} 
Cubans were not without advocates on the outside, however, and their situation drew support from religious and civil rights organizations as time went on. In October of 1984, tensions escalated at the Atlanta penitentiary after guards tried to put down a demonstration during which Cubans wielded banners made of bedsheets reading "Liberty or Death," resulting in a fire and a group of Cubans seizing a cell block for several hours. In retaliation, Mariel Cubans at Atlanta were placed on lockdown for two years. Patrick O'Neill, who was serving time in the adjacent minimum-security facility for anti-nuclear activism, relayed to the media that the prison had also confiscated and burned Cuban belongings in the yard. After his release, O'Neill, along with friends Carla Dudeck and Sally Sandidge who visited him at the prison, formed the Coalition in Support of Cuban Detainees. They began holding monthly vigils outside the prison on behalf of Cubans, attracting national media attention ${ }^{25}$ (See Figure 5).

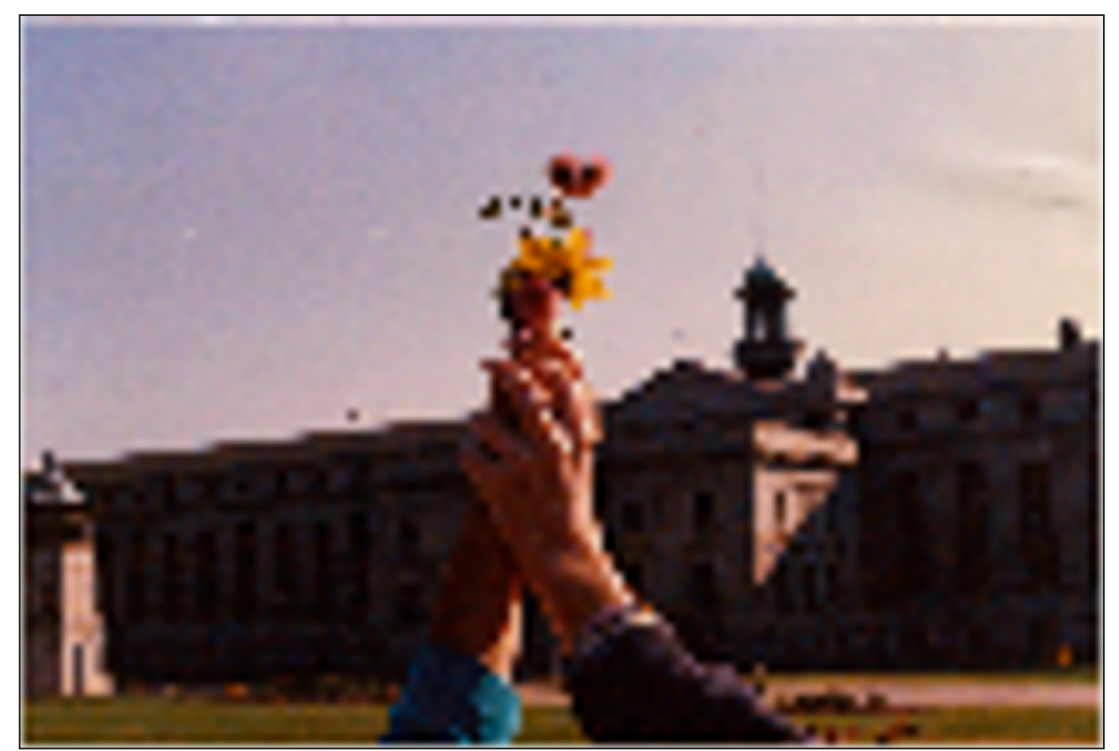

Figure 5: Vigil for Cubans imprisoned at the Atlanta Federal Penitentiary. 1986. Presbyterian Historical Society.

In December of 1984, Cuba agreed to accept 2,746 Mariel Cubans in return for US acceptance of Cuban political prisoners and raising its annual cap of Cuban immigration to the United States to twenty thousand. As US negotiators dictated their list of Cubans to deport late into the night in a smoke-filled room in midtown Manhattan, the Cubans in the room erupted in laughter when the name "Nome Hodes" was read-no me jodes is Spanish for "don't fuck with me," clearly recorded by an unwitting INS agent screening arrivals in $1980 .{ }^{26}$ This was a humorous act of defiance, yet reflective of the US government's lack of knowledge, care, and accurate record-keeping of Mariel Cuban identities and histories. After reaching its agreement with Cuba, the United States deported 201 Cubans in early 1985, but Cuba soon cancelled it when propagandistic US broadcasts of Radio Martí went on the air in May, angering Fidel Castro to the point of calling Reagan the "worst terrorist in the history of mankind," (qtd. in Schoultz 415). US-Cuba talks stalled once again until repatriation negotiations resumed in 1987.

The exceptional legal exclusion and violent conditions inflicted upon Mariel Cubans prompted waves of resistance inside detention that ultimately led to the 1987 uprisings. Still considered "entrants" not technically admitted to the United States, Mariel Cubans who were deemed excludable and detained indefinitely had even fewer due process rights within the already-restrictive world of civil immigration detention. Cuban attempts to challenge their indefinite detention in US courts also came up short. Throughout the 1980s, many Cubans determined eligible for release by INS remained imprisoned, resulting in what Cubans called "pocket freedom"-freedom on paper but not in practice. ${ }^{27}$ Cubans were also not released due to a lack of sponsors on the outside and a lack of space in halfway houses, exacerbated by Reagan-era public funding cuts. This fueled an ongoing sense of betrayal and rage, directed especially at INS.

\footnotetext{
25 See Grimm.

${ }^{26}$ See LeoGrande and Kornbluh pp. 140-4.

27 See Young pp. 128-132.
} 
In the summer of 1987, INS District Director Louis Richard described Mariel Cubans still in federal custody: "We've got everything from skyjackers, arsonists, rapists, murderers, aggravated assaults, crimes of virtually every type you can think of. A couple hundred are hard-core deviates that do strange things. They are psycho cases. I would be for keeping these people in jail for the rest of their lives before I would take a chance on letting one harm your child" (Hamm 80). Reflecting homophobia, and ableism underlying immigration restriction more broadly, these comments also reveal how Mariel Cuban migrants in particular were simultaneously criminalized and pathologized. However, testimonies of imprisoned Cubans shared with advocacy groups, lawyers, and the media detailing abusive prison conditions contrasted sharply with official narratives.

In all, 2,400 imprisoned Cubans at both facilities participated in the longest prison takeover in US history, which cost the US government $\$ 110$ million, including law enforcement attempts to quell the rebellion, property damage, and rebuilding. ${ }^{28}$ Although the standoff ended peacefully with a promise to halt deportations and provide individual case review, INS would largely renege on this promise. Mariel Cubans were, once again, dispersed across the US prison landscape, and forgotten.

As Cubans carefully staged negotiations during the siege, leveraging hostages, the media, and religious and pro-US messaging to demand compassion, they raised public awareness of the injustice of their prolonged detention. Through a FOIA request, I obtained the Department of Justice's documentation of the negotiations process, led by Bureau of Prisons director Michael Quinlan and attorney general Edwin Meese. These records reveal how the US government's continued racial profiling, antipathy, and disregard of Cuban life exacerbated the crisis.

During negotiations, Cubans ran both prisons in a coordinated, theatrical manner, staging threats of violence to gain media access, with support from The Coalition to Support Cuban Detainees in Atlanta and lawyer Gary Leshaw. Cuban-American Auxiliary Bishop Agustin Román from Miami played a mediating role as a spiritual advisor for many. On November 24, Cubans submitted a handwritten list of demands to negotiators at Oakdale, for INS eyes only. It reads: "We the Cuban detainees here at FDC Oakdale have been incarcerated in an average of 8 years ... Because we know how the system is run, we feel that we should be treated likewise ... we feel the INS has not lived up to its promise. We have lost faith in the INS" (Martin). They cited the "undue stress and emotional turmoil" placed on themselves and their families in the United States caused by their indefinite incarceration, and "not being treated as human but more as animals being caged to see what our behavior will be" (Martin). Importantly, Cubans lay blame solely on INS, making clear that BOP, other incarcerated citizens, and prison staff did not have "any part in this situation. They were unfortunate to be here with us when we had gotten enough of injustice" (Martin).

The government brought in a host of "impartial" mediators, mostly from the Cuban-American exile community in Miami, including CANF leader Jorge Mas Canosa and former Cuban political prisoner Armando Valladares, whose presence Cubans booed. In his memoir, imprisoned Mariel Cuban Enrique González Sarasa explains their mistrust of the Cuban-American representatives: "We did not accept them and we told them to go to hell" (qtd. in Young 146). Cubans demanded instead that Gary Leshaw and Auxiliary Bishop Augustin Román of Miami be included in negotiations. At Atlanta, Cubans wrote Leshaw's name on signs and in graffiti on the prison walls. On November 28, Cubans held a bedsheet in front of television cameras, reading: "America, do not be deceived. The BOP is delaying release by denying Archbishop San Roman [sic] from attesting to the agreement. Why?" (Rezendes). ${ }^{29}$ Meese repeatedly rejected this option due to Román's liberal politics, while the Coalition to Support Cuban Detainees in Atlanta reported to the Washington Post that the warden at Atlanta invited Román, but then Quinlan told him not to come because it would be too "disruptive." The standoff continued.

The Department of Justice's documentation of negotiations reveals the US government's imperial gaze, as well as its raced, gendered, and ableist characterizations of imprisoned Mariel Cubans. Noting that the lead Cuban negotiators were "homosexuals," DOJ notes also describe "no real leadership," dismissing the horizontal and inside-outside organizing that had built communication networks via phone and written correspondence between detention sites over the years leading up to the coordinated dual-prison takeover. Meese's refusal to include Cuban advocates in negotiations and Cubans' mistrust of INS stalled negotiations. An FBI psychological profile of Mariel Cubans, also in DOJ's files, lists the following as "typical psychological characteristics" of the "Cuban majority":

\footnotetext{
${ }^{28}$ See Young p. 121.

${ }^{29}$ See also Young pp. 144-5; Hamm p. 26.
} 
1. Low tolerance for frustration

2. Impulsive; seek immediate gratification wishes

3. Concrete thinking; low average intelligence

4. Willing to take risks without considering consequences

5. Psychologically naive; able to be influenced by more sophisticated manipulators

6. Criminal mind-set due to time served in U.S. and Cuban prisons

7. Exaggerated pride in masculinity and bravado

8. Emotionally labile; quickly shift emotions (sometimes in a matter of minutes) from one extreme to another

9. Minimal social skills; unable to function in a complex society

10. Unrealistic hopes and aspirations about life/freedom in U.S.

11. Positive feelings for U.S. but negative feelings toward U.S. government. (Revell and Clarke)

The memo continues by summarizing the "model Cuban prisoner" as someone who is "both culturally disadvantaged and developmentally retarded" (Revell and Clarke). While able to distinguish right from wrong, he is "primitive," but with "street sense," and "willing to lie and take advantage of situations" (Revell and Clarke). He "is only capable of holding the lowest paying jobs," and finally, he has "neither the self discipline nor the patience required to better himself through more acceptable social ways" (Revell and Clarke).

This declassified file speaks volumes-revealing the US government and INS's conflation of criminality with assumptions about Blackness, gender-queerness, disability, and a backwards, feminized, communist Cuba more broadly. However, it also notes prison's ill effects-conceding that imprisonment itself creates criminality. Seven years after Mariel, it was apparent that the highest levels of the US government had written off the humanity of "undesirable" Mariel Cubans still in custody. This much was clear in the retaliation meted out to those involved in the uprisings.

As the most visible flashpoint in the long Mariel crisis, the uprisings were another catalyzing event, inviting state retaliation that would further reinforce detention architectures. Two weeks after the prison siege ended, Meese assured, "Nobody is going to be treated leniently. Nobody is going to be in a better situation than they were in before the uprising" (Coates). Mariel Cubans from Oakdale and Atlanta were immediately transferred to prisons across the country. Although BOP adopted a new policy of dispersal that no more than thirty Mariel Cubans would be held in any one facility, 719 were sent to Leavenworth, Kansas, exceeding the prison's capacity of 827 to 1,900. There, Cubans experienced extreme overcrowding, inadequate meals, communication cut-offs, punitive lockdowns, and abuse, such as being chained naked to their bunks and left alone for hours. ${ }^{30}$ In a letter to the Coalition to Support Cuban Detainees, Arnaldo Rivas wrote, "It is a general feeling that we are not only being mistreated but also treated worse than animals" (qtd. in "Transferred detainees detail abuse"). Ultimately, INS failed to fulfill Meese's promise to review individual cases in a fair and timely manner. In the meantime, Oakdale was rebuilt and reopened in 1989 as a federal detention center for "criminal aliens," buttressed by new laws affirming crimmigration by decade's end.

Mariel Cuban hunger strikes and inside-outside organizing continued as their communications with advocates revealed the extent of US government retaliation and betrayal. Six Cubans who had been transferred to the Metropolitan Correctional Center in Chicago and experienced "mental torment" and "repression" wrote to coalition advocate Steve Donziger in Atlanta, who relayed their messages to the press. Leonardo Jimenez, formerly at Oakdale, said Cubans were planning to go on hunger strike if they did not receive news on their cases by December $30^{\text {th }}$. "The hunger strike will be the only way to make them give our freedom," he wrote, and continued, "Freedom or Death! We have a few old men with us, they are ready to die for their freedom, too" (qtd. in Sly 3). Carla Dudeck of the coalition relayed to the media that 101 Cubans at a prison in Lompoc, California, were also planning a hunger strike. "They're pretty consistent," she said of the conditions described in Cubans' letters. "It's the same treatment-lockdown, handcuffs when they leave the cell, no access to news or information regarding their status" (qtd. in Sly 3).

At first, DOJ moved slowly in fulfilling its promise to review all cases, but the process sped up in the spring of 1988. However, as legal advocates and Judge Shoob charged, the INS review process was ambiguous, arbitrary, and outright unfair. ${ }^{31}$ In a House subcommittee hearing on the uprisings in February of 1988 , Atlanta representative and civil rights leader John Lewis blasted the Reagan administration. "It should be less than surprising when they revolt against this system," he said, which he called a "mockery" in "a country

\footnotetext{
30 See Coates.

31 See Batsalel; Hamm; Young.
} 
that has prided itself in welcoming oppressed people yearning for freedom. The last seven years have been wasted years for these Cuban detainees. We have wasted a significant portion of their lives." ${ }^{32}$ Ultimately, 1,400 Mariel Cubans would be paroled after the uprisings; by the end of 1988, fifteen Cubans determined to be "incorrigibly violent criminals" by the Justice Department's new review process were ordered deported and sent to the Talladega prison in Alabama where they were put on "lockdown" to prevent further unrest. By 1990, only half of Mariel Cubans whose cases had been reviewed had been released. Lawyers working on behalf of Cubans, including Rafael Peñalver, a Cuban-American who helped Auxiliary Bishop Román broker negotiations, promised to continue supporting Mariel Cubans and protesting deportations.

Fifteen Mariel Cubans in Alabama who were ordered deported after the uprisings appealed to a federal court in Birmingham, but lost. Deportations in small groups began, and resistance continued. In August of 1991, 121 Cubans rebelled at the Talladega prison, taking over a cell block and ten hostages. Auxiliary Bishop Román once again served as an intermediary, but after ten days a special operations team of two hundred $\mathrm{BOP}$ and FBI agents raided the prison, effectively putting down the rebellion. By this time, patterns of resistance and retaliation in detention were firmly in place.

Reagan's commitment to expanding migrant detention and the carceral state more broadly, coupled with the US government's indefinite detention of Mariel Cubans, exacerbated a growing "crisis" of prison overcrowding, creating a feedback loop justifying the system's expansion. Cubans were not the only immigrant group to be detained en masse during this time. However, the size and scope of the US immigration detention system grew exponentially after the "crisis" of the early 1980s that began with the Mariel Cuban migration and continued as Haitians, Central Americans, and other migrant groups increasingly sought refuge in the United States. Mariel remained a key symbol of the specter of future immigration emergencies for the United States, and narratives surrounding the urgent need to contain the threat of foreign bodies became the counterpart of a renewed white nationalist vision of who was to be included in the nation.

By the decade's end, even the Cuban American National Foundation had incorporated "lessons" from Mariel in its immigration policy recommendations. In line with its anti-Castro stance, CANF's 1990 Report of the Commission on a Free Cuba warned of the need to mitigate the negative fallout of mass migration in the event of democratic regime change in Cuba. The report's executive summary states: "Such large-scale movements present public health and safety and economic concerns, as was demonstrated by the experience of the 1980 Mariel Boatlift. To avoid a repetition of that experience, the Commission calls for a coordinated FederalState-local plan" (CANF). It recommended interagency and intelligence cooperation, for Congress to fully fund immigration enforcement contingency plans "before a crisis occurs," and "continuous monitoring of potential threats." Indeed, CANF formed in 1981 in the wake of Mariel, under advisement from Reagan's National Security Advisor Richard Allen, who hoped the organization would be a public voice in support of US foreign policy in the Caribbean and Central America (Cadava). As CANF grew in political influence, so did narratives of "good" versus "bad" immigrants and bipartisan support for reform measures accompanied by increased enforcement.

Another tragic irony remained: the Mariel migration of 1980 inspired new detention structures and laws that then served to further exclude Cubans after the uprisings. The 1986 Immigration Reform and Control Act (IRCA), most known for its granting of so-called "amnesty" to those currently residing in the United States since 1982 without documentation, ultimately legalized the status of 2.7 million people. However, as its name implies, IRCA also contained provisions expanding immigration enforcement-wedding reform with "control" as a requisite logic guiding future immigration legislation. IRCA also introduced the idea of instituting a program to target non-citizens with criminal convictions for deportation in response to prison overcrowding, further buttressed by the 1986 and 1988 Anti-Drug Abuse Acts-capstones of Reagan's War on Drugs. The 1986 Act established the basis for immigration detainers, which are INS requests to local law enforcement to "hold" someone in order for the federal government to initiate a deportation case. The 1988 Act further expanded criminal penalties for drug offenses, established mandatory minimum sentences, and provided for the deportation of non-citizens convicted of "aggravated felonies"-namely, murder, drug trafficking, and illicit firearms trading. This category would broaden through subsequent reforms over the next decade, creating a widening net targeting migrants for deportation that today includes driving under the influence, shoplifting, and other crimes of "moral turpitude" (C.C.G. Hernández 67). ${ }^{33}$

\footnotetext{
${ }^{32}$ See "Mariel Cuban Prison Riots."

33 As Alexander Stephens discusses in his piece in this issue, the Reagan administration also launched the Criminal Alien Program (CAP) in 1988 with plans to "purge" non-citizens from the criminal legal system by enlisting local law enforcement in assisting the federal government in identifying non-citizens serving time in US prisons and jails to target for deportation. CAP further boosted the emerging private prison industry and continues to drive incarceration rates today.
} 


\title{
Recovering Mariel Cuban Voices
}

\author{
HOPE IS NOT MY INDULGENCE
}

Wild ride day and night

Venturing low and high.

Luxury came once with the wind and left

Soon as it came in.

I was left-confused and alarmed, struggling in the dark.

Hope have always been distant from my heart. It really... never

have come inside.

My loving heart seems to be struck with such bad luck

I find myself fighting in the dark.

The absence of the light have turned me blind

By feel and touch in such darkness I have survived and still

looking for hope to come to me.

\section{- " "Lene stranded from Cuba," New Lisbon Correctional Institution, 2014}

In a prison blog last updated in 2014, Lene posts a letter to the public, "to introduce myself and let you know who I am." He writes of his experiences during the Mariel Boatlift, his version of events in the murder case of Berniece Taylor, and the injustices of his continued incarceration. Signed Lenin, he also shares poetry and artwork from inside depicting a heart still in Cuba, the view from his grandmother's house there that he remembers, and life in prison-the only worlds he has known. To this day, the scars of the Mariel migration and incarceration remain. Many Mariel Cubans remain silent, while other express fears of retribution for speaking out about their experiences. ${ }^{34}$ Despite such fears, a growing number of voices have gained strength in the past decade, supported by community-based memory and storytelling projects.

In 1994, 34,000 Cubans left Cuba for the United States on rafts in what is known as the balseros crisis. The Clinton administration detained Cuban asylum-seekers at Guantánamo Bay, where President Bush Sr. had been detaining Haitian migrants since 1991. Mariel historian Alexander Stephens argues that one of President Clinton's primary goals in devising the "wet foot, dry foot" policy in response to balseros was to avoid "another Mariel" (Stephens). It seems Clinton had learned early in his political career that xenophobia was a winning strategy. While this new administrative rule expanded arriving Cubans' pathways to residency through the 1966 Cuban Adjustment Act, it simultaneously subjected Cuban migrants at sea to exclusion.

That same year, Congress passed the Violent Crime Control and Law Enforcement Act, authorizing an $\$ 8$ billion increase in state construction grants for prisons and boot camps, including two new facilities for "criminal aliens." Unrest in detention continued. In 1995, a series of hunger strikes and small-scale disturbances led by Cubans erupted on a larger scale on June 18 at the for-profit Elizabeth Detention Center in New Jersey. During the unrest, one hundred migrants briefly took two guards hostage, who were uninjured. They instead targeted the architecture of detention itself-breaking windows, destroying furniture, and tearing tables and chairs from the concrete visitation booths. A Cuban man named Akenis Montane Santos said unrest was triggered by administrators dismissing people's complaints of being forced to wear used underwear and drink spoiled milk. Those were not the only causes for complaint-detained migrants also reported a lack of privacy in filthy bathrooms, lights left on twenty-four hours a day, freezing temperatures at night, no outdoor recreation, and being routinely harassed by guards. As historian Mary Rizzo surmises, these acts reflected resentment toward INS's systemic violation of migrants' material rights. ${ }^{35}$

However, such protests did not deter the Clinton administration from passing a package of legislation known as "the 1996 laws" which have spurred the growth of migrant detention and prison privatization most dramatically into the twenty-first century. The Illegal Immigration Reform and Immigrant Responsibility Act (IIRIRA) and the Antiterrorism and Effective Death Penalty Act (AEDPA) broadened the mandate for migrant detention by expanding the list of crimes constituting "aggravated felonies," and thus deportable offenses requiring mandatory detention. In large part due to the 1996 laws, the average daily INS detention population tripled between 1994 and 2001. ${ }^{36}$

\footnotetext{
34 See Granados; Young p. 122.

35 See Rizzo p. 29.

${ }^{36}$ See Eisen pp. 24-5.
} 
Migrant detention in the United States accelerated further after the terrorist attack of September 11, 2001, and subsequent passage of the 2003 USA PATRIOT Act that created the Department of Homeland Security (DHS), with two renamed enforcement branches-Immigration and Customs Enforcement (ICE) and Customs and Border Protection (CBP)-within DHS replacing INS and the Border Patrol, respectively. The act also granted the attorney general exceptional powers to detain immigrants. In 2004, the Intelligence Reform and Terrorism Prevention Act directed DHS to increase detention capacity by at least 8,000 beds each year between 2006 and 2010. In 2009, Senator Robert Byrd added an amendment to the Appropriations Act of 2010 , lobbied for by the private prison industry, introducing what is now a minimum daily detention bed quota of $34,000 .{ }^{37}$ In early 2021 detention numbers have reached their lowest since the bed quota has been put in place due to the COVID-19 pandemic. While the pandemic has laid bare the violent inner workings of detention, it also presents new opportunities for abolition.

The status of Mariel Cubans was allegedly resolved in 2005, when the US Supreme Court ruled the indefinite detention of Cubans who arrived in the boatlift and were deemed deportable in the list agreed upon between Cuba and the United States in 1984 unconstitutional. During oral arguments, the Bush administration said it was no longer involved in repatriation negotiations with Cuba, admitting, "No one is looking for excludables to send back, but if one of the 2,746 gets into trouble," they will be deported (Schoultz 415). For twenty-five years the United States had reserved the right to keep Mariel Cubans imprisoned, even after they had served their sentences for crimes. This ruling freed around 750 Cubans still being detained, but some remained imprisoned and by 2008 Mariel Cuban deportations were still occurring at a rate of $1-2$ every couple of weeks. ${ }^{38}$ Despite the Supreme Court's ruling and increased collaboration between ICE and criminal legal systems, there are no systematic screenings to locate Mariel Cubans still in custody-like Lenin-who have fallen through the gaps.

The Obama administration officially ended the "wet foot, dry foot" policy in 2017 as part of normalizing US-Cuba relations, but one side effect of normalization has been the facilitation of Cuban deportations. Under the Trump administration, Mariel Cubans with criminal pasts were targeted for deportation once again, with ICE's list of those deemed deportable growing into the thousands. Meanwhile, newly arriving asylum-seekers from Cuba have also been detained in increasing numbers, often in private contract facilities. Jose Antonio Hernandez Viera, speaking from the Pine Prairie facility in Louisiana in 2018, says, "They send Cubans back to Cuba. There's something happening, and I'm sure-I'm convinced-that they don't want us here" (Vinson).

Speaking out from and against spaces of incarceration and marginalization, Mariel Cuban memory and detention storytelling projects have grown in number over the past decade, serving to connect past to present, counter public misperceptions about Mariel, heal personal trauma, and disrupt "deserving" versus "undeserving" immigrant narratives that have normalized criminalization. Some projects have been led by Cuban scholars, such as José Manuel García's oral histories of the boatlift or Omar Granados's local story collection and exhibition remembering Cuban detention at Fort McCoy, Wisconsin; others by community organizations such as the Open Heart and Open Arms exhibit and oral history project of the LGBT Center of Central Pennsylvania, or Freedom for Immigrants' detention stories blog IMM Print; and some, by imprisoned Mariel Cubans themselves like Lenin who tell their stories on their own terms.

As the COVID-19 pandemic has torn through prisons and detention sites across the United States over the past year, a new series of hunger strikes, unrest, and calls for abolition have laid abusive conditions inside bare once again. A letter written by Cuban asylum-seeker Reineris Perez González and signed onto by dozens of others detained in Eloy, Arizona, in the fall of 2020 and published online in IMM Print speaks to experiences of timelessness, racial discrimination, vulnerability to COVID-19, lack of safety protocols, and threats made by guards. "This affects us psychologically, being locked up," González writes. "In addition, there's a lot of COVID-19 infections here, but it's impossible to maintain social distancing. We get to see daylight maybe one hour a day. We fled Cuba so we wouldn't be put in prison and here we are, in prison ... We're treated like commodities" (González). ${ }^{39}$

\section{Conclusion}

Tracing the long crisis of Mariel and the extraordinary exclusion of Mariel Cubans exposes gaps-between immigration and criminal legal systems, law and discretion, and left and right politics-that swallowed the lives of those subjected to indefinite detention. At the center of public hysteria over race, gender, immigration, and crime, Mariel Cuban experiences also reveal crucial connections, showing how foreign and domestic policies converged in new incarceration trends.

\footnotetext{
${ }^{37}$ See Chan.

${ }^{38}$ See Schoultz p. 415.

${ }^{39}$ See also Kassie and Marcolini.
} 
And yet voices from Mariel continue to break through. Challenging Cold War, gender, racial, and good versus bad immigrant binaries, stories from detention map what I call abolitionist imaginaries. Recovering voices that have been lost across histories of hyper-incarceration and foreign relations impasses in the years since Mariel reveal alternative trajectories, and can help chart a different future. In "trying hard to survive," Lenin writes in his blog, he is "trying hard to find freedom in all things as I was promised as I entered this country."

\section{Acknowledgements}

I would like to thank the UC-Cuba Academic Initiative, the Goizueta Foundation and the Cuban Heritage Collection at the University of Miami, Open Society Foundations, and the Charles Warren Center for Studies in American History at Harvard University for their generous support of my research. I have deep gratitude for those who speak out from spaces of incarceration and injustice, and who have entrusted me and a wider public with their stories. Special thanks to Anita Casavantes Bradford, Lisandro Pérez, Omar Granados, Emily Rosenberg, and the anonymous reviewers for their feedback, guidance, and support.

\section{Competing Interests}

The author has no competing interests to declare.

\section{References}

A cartoon drawn by Enrique. 1 Nov. 1980. Fort Chaffee Collection, CHC 5175. University of Miami Cuban Heritage Collection, Miami, FL.

A group of older asylum-seekers at Fort Chaffee. 1980. Charles Lee Hughes Fort Chaffee Photograph Collection, University of Arkansas Special Collections, Fayetteville, AR.

Aguirre, Benigno E. "Cuban Mass Migration and the Social Construction of Deviants." Bulletin of Latin American Research, vol. 13, 1994, pp. 155-83. DOI: https://doi.org/10.2307/3338273

Aguirre, B.E., Rogelio Sáenz, and Brian Sinclair James. "Marielitos Ten Years Later: The Scarface Legacy." Social Science Quarterly, vol. 78, no 2, 1997, pp. 487-507.

Alvarez, Manuel. "Testimony of Manuel Alvarez Machado." Box 2, Folder 2, Fort Chaffee Collection, CHC 5175. University of Miami Cuban Heritage Collection, Miami, FL.

Anti-Castro drawing by an unnamed Mariel Cuban detained at Fort Chaffee, Arkansas. 1980. Fort Chaffee Collection, CHC 5175. University of Miami Cuban Heritage Collection, Miami, FL.

Associated Press Briefing. 23 Nov. 1987. Box 1, Folder 23-02. Records Relating to the Oakdale and Atlanta Prison Riots, 11/23/1987-12/4/19, FOIA Request \#60856, National Archives and Records Administration at College Park, College Park, MD.

Batsalel, Kenneth Aaron. "The Limit(s) of Commitment: Journal Reflections on the Mariel Cuban Repatriation Panel Review Hearings. Dialectical Anthropology, vol. 17, no. 1, 1992, pp. 85-111. DOI: https://doi.org/10. 1007/BF00244456

Bush, George. Letter to Frank White. 3 June 1981. Box 8, Folder "Detention Center and Chaffee Working Files (2)," Francis S.M. (Frank) Hodsoll Files. Ronald Reagan Library, Simi Valley, CA.

Cadava, Geraldo. The Hispanic Republican: The Shaping of an American Political Identity, from Nixon to Trump. Harper Collins, 2020.

Camp, Jordan T. Incarcerating the Crisis: Freedom Struggles and the Rise of the Neoliberal State. University of California Press, 2016. DOI: https://doi.org/10.1525/california/9780520281813.001.0001

Capó, Julio Jr. "Queering Mariel: Mediating Cold War Foreign Policy and US Citizenship Among Cuba's Homosexual Exile Community, 1978-1994." Journal of American Ethnic History vol. 29, no. 4, 2010, pp. 78-106. DOI: https://doi.org/10.5406/jamerethnhist.29.4.0078

--.. "The White House Used This Moment as Proof the U.S. Should Cut Immigration. Its Real History Is More Complicated." Time, 4 Aug. 2017, time.com/4888381/immigration-act-mariel-boatlift-history/.

Castro, Fidel. "Speech by Cuban President Fidel Castro at International Workers' Day Rally Held at José Martí Revolution Square, Havana." 1 May 1980, www.marxists.org/history/cuba/archive/castro/1980/05/01. htm.

Chan, Jennifer. "Immigration Detention Bed Quota Timeline." National Immigrant Justice Center, 13 Jan. 2017, immigrantjustice.org/sites/default/files/ImmigrationDetentionBedQuotaTimeline_2015_12_09. pdf. DOI: https://doi.org/10.1080/09627251.2015.1026220

Chang-Moy, Fernando. Fernando Chang-Moy Oral History Interview. 6 Jan. 2019. LGBTQ Marielitos Oral History Project, William Way LGBT Community Center, Philadelphia, PA. digital.wilcoxarchives.org/ islandora/object/islandora\%3A454. 
Coates, Guy. "Meese Says Riot Ringleaders Will Be Punished." Associated Press, 16 Dec. 1987.

Cuban-American National Foundation. "Report of the Commission on a Free Cuba." 1990.

"Cuban Prisoners in Rebellion." Presbyterian Historical Society, 17 Oct. 2019, www.history.pcusa.org/ blog/2019/10/cuban-prisoners-rebellion.

Deni. Note to Richard. 27 Aug. 1983. Box 2, Folder “2-10.” Alina Fernandez Papers. University of Arkansas Special Collections, Fayetteville, AR.

Dow, Mark. American Gulag: Inside U.S. Immigration Prisons. University of California Press, 2004. DOI: https://doi.org/10.1525/9780520939271

Draft Presidential Crime Speech. Box 16. Statements/Testimony, Others. Subject Files of Rudolph Giuliani, Record Group 60. National Archives and Records Administration at College Park, College Park, MD.

Eisen, Lauren. Inside Private Prisons: An American Dilemma in the Age of Mass Incarceration. Columbia University Press, 2018. DOI: https://doi.org/10.7312/eise 17970

Erickson, Philip. "The Saga of Indefinitely Detained Mariel Cubans: Garcia Mir v. Meese." Loyola Los Angeles International and Comparative Law Review, vol. 10, no. 271, 1988, pp. 271-298.

Fernández, Gastón A. The Mariel Exodus: Twenty Years Later: A Study on the Politics of Stigma and a Research Bibliography. Ediciones Universal, 2002.

García, José Manuel. Voices from Mariel: Oral Histories of the 1980 Cuban Boatlift. University of Florida Press, 2018. DOI: https://doi.org/10.2307/j.ctvx06zgb

Garcia, Margarita. "The Last Days in Cuba: Personal Accounts of the Circumstances of the Exit." Migration Today, vol. 11, no 4-5, 1983, pp. 13-22.

García, María Cristina. Havana USA: Cuban Exiles and Cuban Americans in South Florida, 1959-1994. University of California Press, 1996.

González, Reineris Perez. "A Cuban Asylum Seeker in Detention Speaks Out." IMM Print, 4 Nov. 2020, immprint.com/a-cuban-asylum-seeker-in-detention-speaks-out/.

Granados, Omar. "Cubans in the Tundra: The 1980 Cuban Refugee Program of Fort McCoy." Cuban Counterpoints, September-October 2016, cubacounterpoints.com/archives/3400.html.

Greene, Judith A., Bethany Carson, and Andrea Black. Indefensible: A Decade of Mass Incarceration of Migrants Prosecuted for Crossing the Border. Grassroots Leadership and Justice Strategies, 2016, grassrootsleadership.org.

Grimm, Fred. "Inmate advocates forgotten, nearly broke as cause wanes." Miami Herald, 20 Dec. 1987, p. A-14.

Hamm, Mark S. The Abandoned Ones: The Imprisonment and Uprising of the Mariel Boat People. Northeastern University Press, 1995.

Hay, Michelle A. "I've Been Black in Two Countries": Black Cuban Views on Race in the United States. El Paso, LFB Scholarly Publishing, 2009.

Hernández, César Cuauhtémoc García. Migrating to Prison: America's Obsession with Locking Up Immigrants. The New Press, 2019.

Hernández, Kelly Lytle. City of Inmates. University of North Carolina Press, 2017.

Hoeffel, Paul Heath. "Fort Chaffee's Unwanted Cubans." New York Times, 21 Dec. 1980.

Jackson, Jesse. Telegram from Jesse Jackson to Ronald Reagan. 27 July 1984. Box 61, ID\#182500-564999, WHORM: Subject Files. Ronald Reagan Presidential Library, Simi Valley, CA.

Jorge. Undated Letter. Box 2, Folder 2, Fort Chaffee Collection, CHC 5175. University of Miami Cuban Heritage Collection, Miami, FL.

Kanstroom, Dan. Deportation Nation: Outsiders in American History. Harvard University Press, 2007.

Kassie, Emily, and Barbara Marcolini, "'It Was Like a Time Bomb': How ICE Helped Spread Coronavirus." New York Times, 25 April 2021, www.nytimes.com/2020/07/10/us/ice-coronavirus-deportation.html.

Kornbluh, Peter and LeoGrande, William M. Back Channel to Cuba: The Hidden History of Negotiations between Washington and Havana. University of North Carolina Press, 2014.

La Libertad. 1 Aug. 1980. Box 36. Cuban Haitian Task Force Files. Carter Presidential Library, Atlanta, GA.

Larzelere, Alex. The 1980 Cuban Boatlift: Castro's Ploy-America's Dilemma. National Defense University Press, 1988.

Lene. "Hope is Not My Indulgence." 2014, lenescespedes.blogspot.com/2013/11/lokk-into-my-eyes-andcome-inside.html.

Lindskoog, Carl. Detain and Punish: Haitian Refugees and the Rise of the World's Largest Immigration Detention System. The University of Florida Press, 2018. DOI: https://doi.org/10.5744/florida/978168 3400400.001.0001 
Lipman, Jana K. "A Refugee Camp in America: Fort Chaffee and Vietnamese and Cuban Refugees, 19751982." Journal of American Ethnic History, vol. 33, no. 2, 2014, pp. 57-87. DOI: https://doi.org/10.5406/ jamerethnhist.33.2.0057

Loyd, Jenna M. and Alison Mountz. Boats, Borders, and Bases: Race, the Cold War, and the Rise of Migrant Detention in the United States. University of California Press, 2018. DOI: https://doi.org/10.1525/ california/9780520287969.001.0001

Macías-Rojas, Patricia. From Deportation to Prison: The Politics of Immigration Enforcement in Post-Civil Rights America. NYU Press, 2016. DOI: https://doi.org/10.18574/nyu/9781479804665.001.0001

Maraniss, David. "Cuba Exiles Holding 20 As Hostages.” Washington Post, 23 Nov. 1987.

"Mariel Cuban Prison Riots." House Judiciary Subcommittee on Courts, Civil Liberties, and the Administration of Justice hearing, 4 Feb. 1988.

Martínez, Guillermo. "Mariel Myths Feed Venom Across Nation." Miami Herald, 18 Nov. 1982, p. 31A.

Martin, Steve. Handwritten letter from Steve Martin to Alan Nelson. 25 Nov. 1987. Box 1, Folder 25-03, Records Relating to the Oakdale and Atlanta Prison Riots, 11/23/1987-12/4/19, FOIA Request \#60856. National Archives and Records Administration at College Park, College Park, MD.

Operational and Policy Issues at Fort Chaffee. 5 March 1981. Box 1, Barbara Lawson: Cuban-Haitian Task Force Documents 1980-1981, Fort Chaffee Collection, CHC 5175. University of Miami Cuban Heritage Collection, Miami, FL.

Peña, Susana, “'Obvious Gays' and the State Gaze: Cuban Gay Visibility and U.S. Immigration Policy during the Mariel Boatlift." Journal of the History of Sexuality, vol. 16, no. 3, 2007, pp. 482-514. DOI: https://doi. org/10.1353/sex.2007.0072

---. iOye Loca! From the Mariel Boatlift to Gay Cuban Miami. University of Minnesota Press, 2013.

Revell, O. B., and F.I. Clarke. Memo to FBI Director. 29 Nov. 1987. Box 1, Folder 30-03, Records Relating to the Oakdale and Atlanta Prison Riots, 11/23/1987-12/4/19, FOIA Request \#60856. National Archives and Records Administration at College Park, College Park, MD.

Rezendes, Michael. "Miami Prelate May Be Key in Oakdale." Washington Post, 20 Nov. 1987.

Rizzo, Mary. "Finding the Disappeared: The Immigration Detention Archive Conundrum." Latterly, 15 May 2016, medium.com/latterly/finding-the-disappeared-the-immigration-detention-archive-conundrumfc1b84a13b8f.

Schoultz, Lars. That Infernal Little Cuban Republic: The United States and the Cuban Revolution. University of North Carolina Press, 2011.

Segal, Mark. Mark Segal Oral History Interview. 6 Jan. 2019. LGBTQ Marielitos Oral History Project, William Way LGBT Community Center, Philadelphia, PA, digital.wilcoxarchives.org/islandora/object/ islandora\%3A454.

Shull, Kristina. “'Nobody Wants These People': Reagan's Immigration Crisis and the Containment of Foreign Bodies." Body and Nation: The Global Realm of U.S. Body Politics in the Twentieth Century, edited by Emily S. Rosenberg and Shanon Fitzpatrick, Duke University Press, 2014, pp. 241-263. DOI: https://doi. org/10.2307/j.ctv120qsd2.15

--- "Reagan's Cold War on Immigrants: Resistance and the Rise of a Detention Regime, 1981-1985." Journal of American Ethnic History, vol. 40, no. 2, 2021, pp. 5-51. DOI: https://doi.org/10.5406/ jamerethnhist.40.2.0005

Sierra Madero, Abel. Del otro lado del espejo: La sexualidad en la construcción de la nación cubana. Casas de las Américas, 2006.

---. "Memorias del Mariel: Actos de repudio y violencia colectiva en Cuba." El nuevo Herald, 1 May 2018.

Significant Activities. 18 May 1980. Box 1, Gastón A. Fernández: Federal Control Center Documents, 1980 (1/2), Fort Chaffee Collection, CHC 5175. University of Miami Cuban Heritage Collection, Miami, FL.

Simon. Written testimony. June 17, 1980. Box 2, Fort Chaffee Collection. Cuban Heritage Collection, University of Miami, Miami, FL.

Simon, Jonathan. Governing Through Crime: How the War on Crime Transformed American Democracy and Created a Culture of Fear. Oxford University Press, 2007.

Sly, Liz. "Cubans complain of isolation, abuse." Newsday, 23 Dec. 1987, p. 3.

Stephens, Alexander M. "Wet Foot, Dry Foot: The Mariel Boatlift and the dangerous persistence of Memory." IEHS Online, 21 Feb. 2018, www.iehs.org/alexander-stephens-wet-foot-dry-foot/.

Termination of Ft. Chaffee Operations. n.d. Box 10, Folder "Immigration Policy: Cubans and Haitians," James Cicconi Files. Ronald Reagan Library, Simi Valley, CA.

"Transferred detainees detail abuse." Chicago Tribune, 29. Dec. 1987, pp. 1-8. 
Two gender non-conforming individuals grooming in their barracks at Fort Chaffee. 1981. Charles Lee Hughes Fort Chaffee Photograph Collection. University of Arkansas Special Collections, Fayetteville, AR.

Vigil for Cubans imprisoned at the Atlanta Federal Penitentiary. 1986. Box 19, Folder 6, RG 519. Presbyterian Historical Society, Philadelphia, PA.

Vinson, Liz. "Immigrant Prison ‘Driving Him Crazy'." Southern Poverty Law Center, 8 Apr. 2019, https://www. splcenter.org/attention-on-detention/immigrant-prison-\%E2\%80\%98driving-him-crazy\%E2\%80\%99.

Young, Elliott. Forever Prisoners: How the United States Made the World's Largest Immigrant Detention System. Oxford University Press, 2021. DOI: https://doi.org/10.1093/oso/9780190085957.001.0001

Zolberg, Aristide. America by Design: Immigration Policy in the Fashioning of America. Harvard University Press, 2006.

How to cite this article: Shull, K 2021 Somos los Abandonados: Mariel Cuban Stories from Detention and Resisting the Carceral State. Anthurium, 17(2): 5, 1-21. DOI: https://doi.org/10.33596/anth.445

Published: 14 December 2021

Copyright: $\odot 2021$ The Author(s). This is an open-access article distributed under the terms of the Creative Commons Attribution 4.0 International License (CC-BY 4.0), which permits unrestricted use, distribution, and reproduction in any medium, provided the original author and source are credited. See http://creativecommons.org/licenses/by/4.0/. 